\title{
Clean Air Act: Awareness and Opinions Among Marine Engineering Students
}

\author{
Rolando A. Alimen, E. Julio Oberiano, and E. Arturo Villanueva \\ College of Maritime Education, John B. Lacson Foundation Maritime University-Molo, Philippines
}

\begin{abstract}
This study aims to determine the awareness and opinions on Clean Air Act among marine engineering students at maritime university, specifically, John B. Lacson Foundation Maritime University-Molo, Iloilo City, Philippines. The participants of this study were 30 marine engineering students of the maritime university, especially JBLFMU-Molo for school year 2014-2015. Participants of the study were enrolled at the College of Maritime Education, JBLFMU-Molo, Iloilo City, Philippines. The researchers employed quantitative research design. The respondents' comments, suggestions, observations, and remarks on the perceived awareness and opinions on Clean Air Act were captured in this study. After gathering the qualitative information, the researchers classified and categorized the write-ups of the respondents into different categories. The results reveal that the participants of the present study were aware of the Clean Air Act as an entire group and when classified according to different categories. Most of the participants said that Clean Air Act protects the environment, followed by the participants who said that Clean Air Act can prevent air pollution. Next, in rank, the participants who said "it is good because you can go everywhere to inhale fresh air, followed by participants who said Clean Air Act can reduce the things that can harm the ozone layer, the last participants said that they never heard of Clean Air Act.
\end{abstract}

Key words: Clean Air Act, awareness, opinions, marine engineering students.

\section{Introduction}

Establishing policy on balanced development and environmental protection is one of the concerns of every state, specifically, Philippines. The RA 8749 commonly known as Philippine Clean Air Act was created to address primarily on pollution prevention and to provide for comprehensive management program for air pollution. This is the call to promote public information and education encouraging more participation of informed and active public about air quality planning and monitoring.

The right to breathe clean air and enjoy the natural resources is the main concern of everyone here on earth. However, air pollutants level in the atmosphere and surrounding are found out to be above the required concentration. These concentrations are detrimental to health and environment. Reducing air

Corresponding author: Rolando A. Alimen, Ph.D., research fields: maritime, environment, engineering, and physics. E-mail: ralimen@yahoo.com. pollution and creating sizeable health benefits would affect ecological-systems friendly and human health, which would give impact to the operation and function of any society.

Regulation on cleaner air or quality air and method for enforcing standards would somehow control the air pollution and protect the stratospheric-ozone layer. This is one of the initiatives that should be in placed as suggested by Shepherd, Hornback, Furst, Holloway (1995).

The Clean Air Act was used to provide insights among policy makers to address issues on air pollution and health problems (US Environmental Protection Agency Office of Air and Protection, 2011).

In this regard, the present study was conceived. This study was conducted to gather information on perception or awareness of certain group on the air pollution. It may be used to determine somehow the local ordinances institutionalizing the Clean Air Act at certain local or municipality. 


\section{Statement of the Problem}

In order to understand the present study, the specific questions were advanced:

(1) What is the awareness of the respondents on Clean Air Act as an entire group and when classified according to different categories such as: (a) age, (b) type of school, and (c) type of residence?

(2) What are the opinions of the respondents on the Clean Air Act?

\section{Conceptual Framework}

The present study presents the inter-relationship of the variables leading to awareness of Clean Air Act as influenced by related factors such as age, type of school, and type of residence among the respondents.

\section{Theoretical Framework}

The present study was anchored on the principle advocating the right to breathe clean air (Clean Air Act - RA 8749). The framework focuses to the activities and initiatives leading to the reduction of air pollution that would influence premature deaths and illness. However, the theory was used to determine the level of awareness and opinions on Clean Air Act (RA 8749) of certain group at certain particular time of study.

\section{Method}

\subsection{Research Design}

This study utilized qualitative approach of research. A researcher-made questionnaire was made for this purpose. The data derived from the questionnaire elicited data on the awareness on Clean Air Act among students at maritime university. Qualitative information was used to enhance the quantitative research results. This approach is necessary because of the wide range of data needed to develop effective data source important in this investigation. This study specifically used the quantitative and qualitative approach to achieve the objectives of this study.

The participants of the present study were thirty (30) marine engineering students of JBLFMU-Molo, Iloilo City for the School Year 2014-2015. The participants whose age ranges from 19 years old and above were $16(53 \%)$ and those whose age ranges from 13 to 18 years old were $14(47 \%)$ participants. As to the type of school graduated from, $15(50 \%)$ students came from private schools and $15(50 \%)$ came from public schools. In reference to the type of residence, $18(60 \%)$ participants came from urban area and $12(40 \%)$ participants came from rural area.

Data are shown in Table 1.

\subsection{Awareness of the Participants on Clean Air Act}

As reflected in Table 2, majority $(20,67 \%)$ of the participants was aware of the Clean Air Act and few participants were not aware of the act $(10,33 \%)$ as an entire group and when classified according to different categories such as age, type of school graduated from, and type of residence.

\subsection{Opinions of Participants on Clean Air Act}

Most of the participants said that Clean Air Act protects the environment $(8,27 \%)$, followed by seven

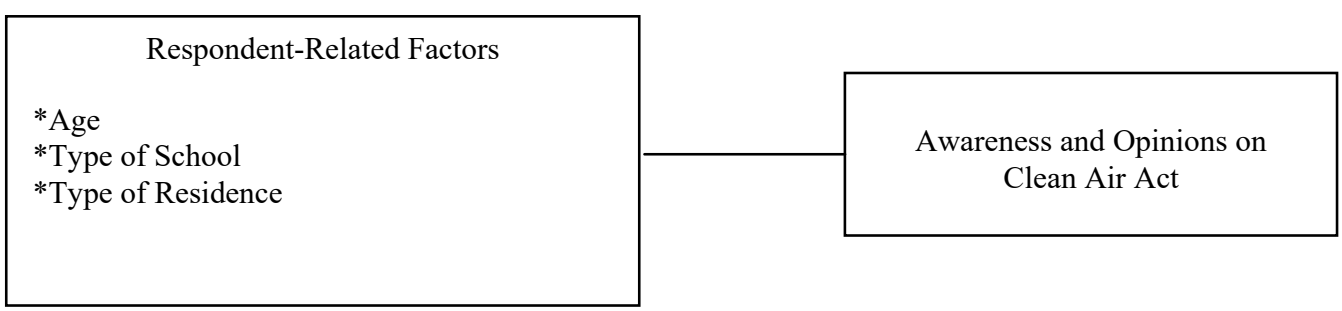

Fig. 1 Awareness and opinions on Clean Air Act as influenced by certain respondent-related factors. 
Table 1 Distribution of participants.

\begin{tabular}{lll}
\hline Category & $\mathrm{f}$ & $\%$ \\
\hline A. Entire Group & 30 & 100 \\
B. Age & & \\
$\quad 19$ years old \& above & 16 & 53 \\
$\quad 13-18$ years old & 14 & 47 \\
C. Type of School Graduated from & & \\
$\quad$ Private & 15 & 50 \\
$\quad$ Public & 15 & 50 \\
D. Type of Residence & & \\
$\quad$ Urban & 18 & 60 \\
$\quad$ Rural & 12 & 40 \\
\hline
\end{tabular}

Table 2 Awareness of the participants on Clean Air Act as an entire group.

\begin{tabular}{lll}
\hline $\begin{array}{l}\text { Awareness of the Respondents on } \\
\text { Clean Air Act as an entire group }\end{array}$ & $\mathrm{f}$ & $\%$ \\
\hline Yes & 20 & 67 \\
No & 10 & 33 \\
Total & 30 & 100 \\
\hline
\end{tabular}

(7, 23\%) participants who said that Clean Air Act can prevent air pollution. Third in rank, six $(6,20 \%)$ participants out of 30 said it is good because you can go everywhere to inhale fresh air, five (5, 17\%) participants said Clean Air Act can reduce the things that can harm the ozone layer, only four $(4,13 \%)$ said that they never heard of Clean Air Act. As mentioned by the participants, Clean Air Act may control the air exhausted from the industrial and mobile sources. Air quality shall be the main concern of this act through the strict implementation of regulations leading to protect the stratosphere and ozone layer. Local ordinances shall be instituted to reduce carbon emission and chemicals-exhaust products.

Table 3 Awareness of the respondents on Clean Air Act according to Age.

\begin{tabular}{lll}
\hline $\begin{array}{l}\text { Awareness of the respondents on } \\
\text { Clean Air Act According to Age }\end{array}$ & $\mathrm{f}$ & $\%$ \\
\hline A. 19 years old \& above & 13 & 82 \\
Yes & 3 & 18 \\
No & & \\
B. 13 -18 years old & 11 & 79 \\
Yes & 3 & 21 \\
No & 3 \\
\hline
\end{tabular}

Table 4 Awareness of respondents on Clean Air Act as classified according to type of school.

\begin{tabular}{lll}
\hline $\begin{array}{l}\text { Awareness of the Respondents on Clean } \\
\text { Air Act according to Type of School } \\
\text { Graduated from }\end{array}$ & $\mathrm{f}$ & $\%$ \\
\hline $\begin{array}{lll}\text { A. Private } \\
\text { Yes }\end{array}$ & 12 & 80 \\
No & 3 & 20 \\
B. Public & & \\
Yes & 11 & 73 \\
No & 4 & 27 \\
\hline
\end{tabular}

Table 5 Awareness of respondents on Clean Air Act as to the type of residence.

\begin{tabular}{lll}
\hline $\begin{array}{l}\text { Awareness of the Respondents on } \\
\text { Clean Air Act Type of Residence }\end{array}$ & $\mathrm{f}$ & $\%$ \\
\hline A. Urban & 15 & 83 \\
Yes & 3 & 17 \\
No & & \\
B. Rural & 10 & 83 \\
Yes & 2 & 17 \\
No & \\
\hline
\end{tabular}

Table 6 Opinions of participants on Clean Air Act.

\begin{tabular}{llll}
\hline Opinions of Respondents on & $\mathrm{f}$ & $\%$ & $\mathrm{R}$ \\
\hline Clean Air Act & 8 & 27 & 1 \\
\hline It protects the environment & 7 & 23 & 2 \\
$\begin{array}{l}\text { Clean Air Act can prevent air pollution } \\
\begin{array}{l}\text { It is good because you can go } \\
\text { everywhere to inhale fresh air }\end{array}\end{array}$ & 6 & 20 & 3 \\
$\begin{array}{l}\text { Clean Air Act can Reduce the things } \\
\text { that can harm the ozone layer }\end{array}$ & 5 & 17 & 4 \\
Never heard of Clean Air Act & 4 & 13 & 5 \\
Total & 30.0 & 100 & \\
\hline
\end{tabular}

\section{Summary of the Findings}

The findings of the present study were the following:

The participants of the present study were aware of the Clean Air Act as an entire group and when classified according to different categories.

Most of the participants said that Clean Air Act protects the environment, followed by the participants who said that Clean Air Act can prevent air pollution. Next, in rank, the participants who said "it is good because you can go everywhere to inhale fresh air, followed by participants who said Clean Air Act can reduce the things that can harm the ozone layer, the last participants said that they never heard of Clean 
Air Act.

\section{Conclusions}

Based on the findings of the present study, the following conclusions were advanced:

(1) Participants of the present study were aware of the Clean Air Act and its influence to the environment and surrounding. The effect has impact on the health and biological aspects of people living in the identified hazard areas.

(2) The participants of the present agreed that Clean Air Act can prevent air because participants said "it is good because you can go everywhere to inhale fresh air." Some of the participants mentioned that Clean Air Act can reduce the things that can harm the ozone layer, and other participants shared that they never heard of Clean Air Act.

\section{Recommendations}

The following recommendations were based on the findings and conclusions of the present study:

(1) The awareness of the participants, specifically, marine engineering students of maritime university shall be sustained and enhanced by adding more activities towards the importance of Clean Air Act.

(2) The comment stating that Clean Air Act can prevent air pollution is good indication that results should be disseminated to other stakeholders, collaborators, and constituents who are engaged on issues about prevention of air pollution.

(3) Parallel studies shall be conducted to determine other variables related to air pollution in order to solicit more views and ideas about Clean Air Act.

\section{References}

[1] US Environmental Protection Agency Office of Air and Protection (2011).

[2] RA 8749- Philippine Clean Air Act of 1999.

[3] Holladay J. S. (2011). Valuing the Clean Air Act: How Do We Know How Much Clean Is Worth? Published by Institute for Policy Integrity. New York University School of Law, USA.

[4] Shepherd P., Hornback J., Furst R. and Holloway J. (1995). The Clean Air Act and Your Small Business.

[5] Bella R. (2011). Basic Practice Series: Clean Air Act, New York University School of Law, USA. 